\title{
WORKSHOP PENGEMBANGAN BAHAN AJAR DI SMK KESEHATAN MARTABE SIPIROK
}

\author{
Fitriani, Wiwik Novitasari, Yulia Anita Siregar \\ Pendidikan Matematika FKIP, Universitas Muhammadiyah Tapanuli Selatan \\ fi3ani.hrp@gmail.com
}

DOI : 10.31604/j.martabe.v1i3.149-157

\begin{abstract}
The process of teaching and learning in schools is crucial to the success of students. In achieving these successes need help and encouragement from teachers and parents. However, in the process of studying in schools that are very much contributing is the role of teachers. In this case, the teacher is demanded in such a way that can bring the students to success thus the new teacher is said to have achieved the goal of learning. In achieving that goal many things to be done one teacher is the development of teaching materials. Therefore, teachers should be able to develop teaching materials or package books that already exist as interesting as possible with simple language and in such a way that students can study independently at school and home with the help of the developed teaching materials. The purpose of this workshop is (1) Increase teachers' knowledge and understanding of teaching materials development. (2) Increase teacher's knowledge and understanding in improving student's learning motivation. (3) Teachers can make the development of teaching materials as interesting and as efficient as possible to be implemented in the learning process. This devotion is implemented in SMK Kesehatan Martabe Sipirok. The implementation method is done in the form of a workshop. Community service is held for three months, in January - March 2016. Where the workshop activities carried out for two days in a row. The result of this teaching materials development workshop is that teachers at SMK Kesehatan Martabe Sipirok have got much motivation, information/knowledge related in the development of teaching materials and also predicted in the future the teachers especially in SMK Kesehatan Martabe Sipirok have been able to develop their teaching materials.
\end{abstract}

Key words: Workshop, Development, Instructional Materials.

\begin{abstract}
Abstrak
Proses belajar mengajar di sekolah sangat menentukan keberhasilan siswa. Dalam mencapai keberhasilan tersebut perlu bantuan dan dorongan dari guru serta orang tua. Namun dalam proses belajar di sekolah yang sangat banyak memberikan kontribusi adalah peran guru. Dalam hal ini guru dituntut sedemikian sehingga mampu membawa para siswa menuju keberhasilan dengan demikian maka guru baru dikatakan telah mencapai tujuan pembelajaran. Dalam mencapai tujuan tersebut banyak hal yang harus dilakukan guru salah satunya adalah pengembangan bahan ajar. Oleh karena, itu guru harus mampu mengembangkan bahan ajar atau buku paket yang sudah ada semenarik mungkin dengan bahasa yang sederhana dan di desain sedemikian rupa sehingga siswa dapat belajar mandiri disekolah maupun di rumah dengan bantuan bahan ajar yang
\end{abstract}


dikembangkan tersebut. Tujuan kegiatan workshop ini adalah (1) Meningkatkan pengetahuan dan pemahaman para guru mengenai pengembangan bahan ajar. (2) Meningkatkan pengetahuan dan pemahaman para guru dalam meningkatakan motivasi belajar siswa. (3) Para guru mampu membuat desain pengembangan bahan ajar semenarik dan seefisien mungkin untuk dilaksanakan dalam proses pembelajaran. Pengabdian ini dilaksanakan di SMK Kesehatan Martabe Sipirok. Metode pelaksanaan yang dilakukan ialah berupa workshop. Pengabdian masyarakat ini dilaksanakan selama 3 bulan, pada bulan Januari - Maret 2016. Dimana kegiatan workshopnya dilaksanakan selama dua hari berturut-turut. Hasil workshop pengembangan bahan ajar ini yaitu bahwa guru-guru di SMK Kesehatan Martabe Sipirok sudah banyak memperoleh motivasi, informasi/pengetahuan terkait dalam pengembangan bahan ajar dan juga diperkirakan kedepannya para guru-guru khususnya di SMK Kesehatan Martabe Sipirok sudah mampu mengembangkan bahan ajar sendiri.

Kata kunci: Workshop, Pengembangan, Bahan ajar.

\section{PENDAHULUAN}

Bahan ajar menurut Widodo dan Jasmadi (Shulhany, 2015) adalah seperangkat sarana atau alat pembelajaran yang berisikan materi pembelajaran, metode, batasan-batasan dan cara mengevaluasi yang didesain secara sistematis dan menarik dalam rangka mencapai tujuan yang diharapkan yaitu mencapai kompetensi atau subkompetensi dengan segala kompleksitasnya. Sedangkan bahan ajar menurut Raharjo (2014) adalah segala bahan (baik itu informasi, alat, maupun teks) yang disusun secara sistematis yang menampilkan sosok utuh dari kompetensi yang akan dikuasai peserta didik dan digunakan dalam proses pembelajaran dengan tujuan untuk perencanaan dan penelaahan implementasi pembelajaran. Berdasarkan hal tersebut maka yang dimaksud dengan bahan ajar ialah suatu perangkat pembelajaran yang didesain oleh guru yang berisikan materi, strategi, serta evaluasi guna mencapai tujuan yang diharapkan. Melalui bahan ajar tersebut tujuan pembelajaran dapat tercapai sesuai dengan yang diharapkan, baik berupa pengetahuan, sikap, dan keterampilan lainnya. Bahan ajar memiliki peran penting dalam pembelajaran, penggunaan bahan ajar yang baik dapat membantu proses pembelajaran di kelas. Bahan ajar dapat dimanfaatkan dalam pembelajaran matematika, namun perlu rancangan khusus agar sesuai dengan materi, prinsip pedagogi, dan menarik bagi siswa, untuk itu perlu dibuat suatu pengembangan bahan ajar. Oleh sebab itu bahan ajar perlu dikembangkan agar tujuan pembelajaran tercapai dengan baik.

Sedangkan pengembangan menurut Majid (2011) pengembangan merupakan upaya dalam rangka menghasilkan inovasi yang tepat untuk diterapkan dalam sistem yang ada. Sehingga pengembangan bahan ajar tersebut berlandaskan pada pengertian bahwa mengajar merupakan suatu bentuk upaya memberikan bimbingan kepada siswa untuk melakukan kegiatan belajar atau dengan kata lain membelajarkan siswa. Sehingga terlihat bahwa belajar tidak semata-mata berorientasi kepada hasil, melainkan juga berorientasi kepada proses. Pengembahan bahan ajar ini memberikan motivasi bagi siswa karena 
Fitriani, dkk. Workshop Pengembangan Bahan Ajar di SMK Kesehatan ...

bahasa dalam bahan ajar ini dirancang sedemikian rupa agar para siswa mudah memahami materi yang diberikan. Pengembangan bahan ajar ini membantu guru dalam proses belajar mengajar dimana para siswa bisa belajar secara mandiri tanpa ada bantuan guru karena bahasa yang digunakan adalah bahasa sederhana.

Namun kenyataannya, berdasarkan hasil wawancara dengan Ibu Yulia Anita Siregar, M.Pd selaku Kepala Sekolah SMK Kesehatan Martabe Sipirok (Jum'at, 16 Desember 2016) menyatakan bahwa guru-guru yang mengajar masih menggunakan bahan ajar yang dibeli dari toko-toko buku dan buku paket yang diberikan oleh pemerintah yang menggunakan bahsa yang tinggi sehingga sulit diapahi oleh para siswa. Selain itu Guru-guru tersebut belum mampu mengembangkan bahan ajar pada mata pelajaran yang diampuhnya terkhusus juga pada guru-guru matematika. Hal ini diperkirakan karena para guru kurang mengetahui atau minim dalam pengetahuan cara-cara dalam mengembangkan suatu bahan ajar, sehingga para guru tidak mampu dalam mengembangkan bahan ajar.

\section{METODE PELAKSANAAN}

Workshop ini dilaksanakan pada guru-guru yang ada di SMK Kesehatan
Martabe Sipirok terkait pengembangan bahan ajar khususnya pada pembelajaran matematika dan umumnya pada proses pembelajaran di SMK Kesehatan Martabe Sipirok. Workshop ini dilaksanakan agar para guru-guru sekolah menengah mampu mengembangkan bahan ajar yang sudah ada sekarang ini sehingga tujuan yang diharapkan dapat tercapai, sehingga motivasi para siswa dalam mengikuti setiap proses pembelajaran di kelas maupun di luar kelas semakin meningkat.

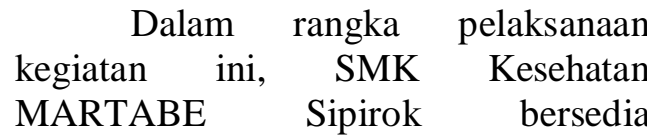
menyediakan ruangan sebagai tempat pelatihan beserta sarana pendukung lainnya seperti komputer, infokus, dan whitebord. Sekolah juga mendukung dalam menfasilitasi urusan administrasi, serta menugaskan semua guru-guru dalam kegiatan ini.

Untuk menganalisis kegiatan workshop ini yaitu dengan cara mendeskriptif hasil kegiatan berdasarkan hasil pengamatan, antusias peserta, dan berdasarkan terlaksananya semua kegiatan workshop pengembangan bahan ajar dalam bentuk narasi/deskripsi kualitatif.

Adapun kegiatan-kegiatan yang akan dilakukan dalam workshop ini secara garis besar adalah sebagai berikut:

Tabel 1: Deskripsi Kegiatan Workshop

\begin{tabular}{|c|c|}
\hline Kegiatan & Deskripsi Kegiatan \\
\hline \multirow{3}{*}{ Tutorial/Persentase } & Hari ke-1 \\
\hline & $\begin{array}{l}\text { - Memotivasi guru-guru terkait betapa pentingnya mengembangkan } \\
\text { bahan ajar. }\end{array}$ \\
\hline & $\begin{array}{l}\text { - Persentase terkai menjelaskan tentang Strategi pembelajaran dan } \\
\text { manfaatnya }\end{array}$ \\
\hline \multirow{5}{*}{ Workshop/persentase } & Hari ke-2 \\
\hline & Persentase terkait: \\
\hline & - Menjelaskan tentang bahan ajar dan manfaatnya \\
\hline & - Menjelaskan tentang pengembangan bahan ajar \\
\hline & - Pembimbingan dalam membuat disain pengembangan bahan ajar \\
\hline
\end{tabular}


HASIL DAN PEMBAHASAN

$\begin{array}{ccr}\text { Kegiatan } & \text { workshop ini } \\ \text { terlaksana sesuai } & \text { dengan yang }\end{array}$ diharapkan. Hal ini dapat dilihat dari hari ke-1 dan ke-2 yang dilakukan dengan pembahasan sebagi berikut:

\section{Hari ke-1}

Kegiatan hari pertama yaitu tim pengabdian masyarakat memotivasi para guru terkait betapa pentingnya mengembangkan bahan dan mempersentasekan ataupun membahas terkait strategi pembelajaran. Dimana strategi pembelajaran ini merupakan salah satu syarat dalam mengembangakan bahan ajar. Berikut adalah foto kegiatan pelaksanaan workshop terkait persentase strategi pembelajaran.

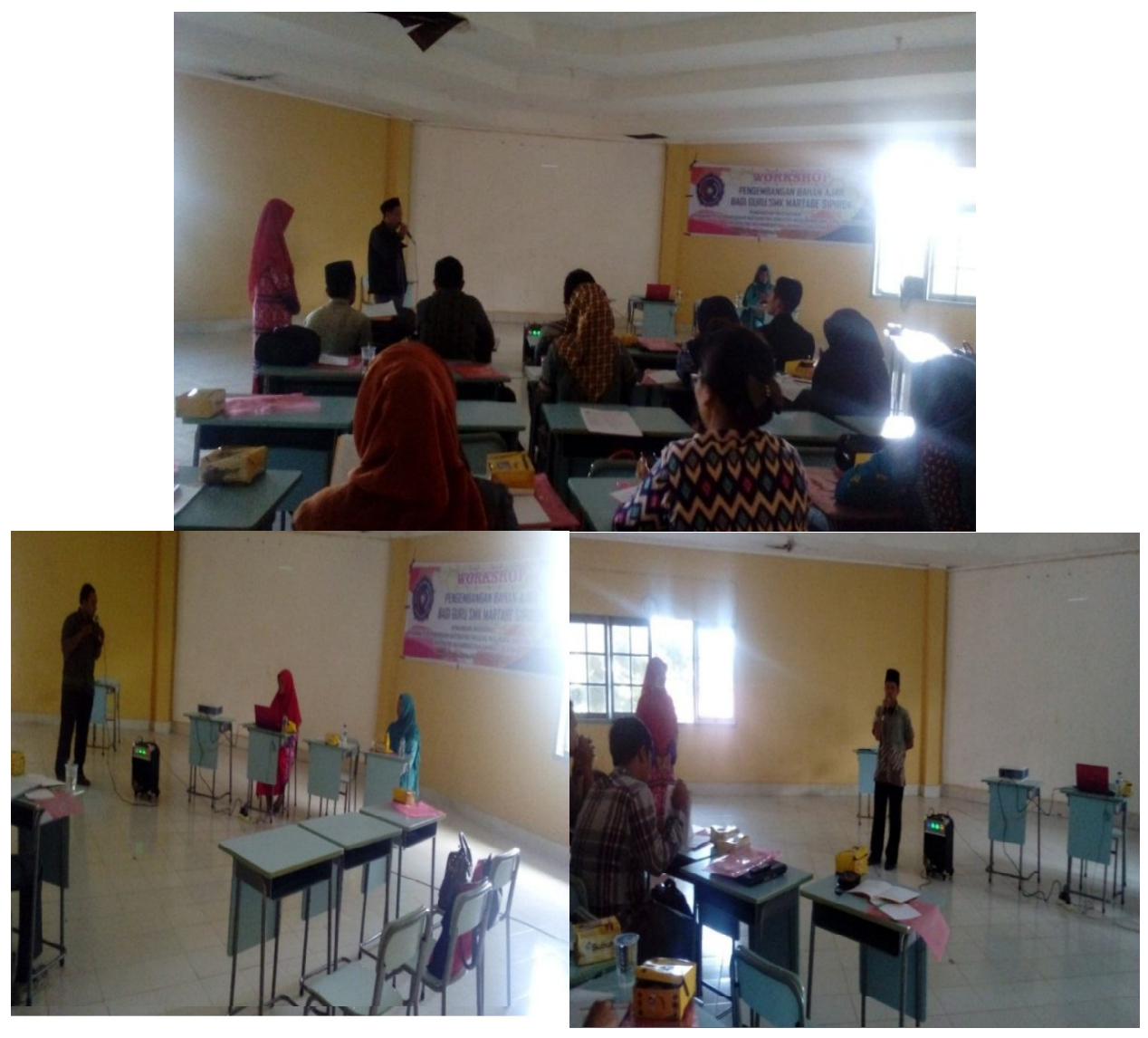

Gambar 1: Antusias peserta dalam mengajukan pertanyaan terkait Strategi Pembelajaran

Kegiatan ini dapat dikatakan terlaksana dengan baik hal ini didasari oleh antusias para peserta dalam mengikuti kegiatan. Ini dapat ditunjukkan berdasarkan banyaknya pertanyaan dari Para peserta. Berikut adalah beberapa pertanyaan yang diajukan oleh peserta kepada narasumber/pemateri:

a) Bagaimana strategi pembelajaran yang tepat kita gunakan ketika kita dihadapkan pada siswa yang pendiam dan tidak mau bertanya ketika proses pembelajaran sedang berlangsung? 
Fitriani, dkk. Workshop Pengembangan Bahan Ajar di SMK Kesehatan ...

b) Strategi pembelajaran yang seperti apa yang kita lakukan ketika kita dihadapkan pada siswa yang memiliki kelainan atau kemampuan siswa yang sangat rendah, tetapi tidak mengganggu terhadap siswa yang lainnya?

c) Bagaimana cara kita mengetahui Strategi pembelajaran yang tepat digunakan dalam proses pembelajaran?

d) Dalam melaksanakan kegiatan proses pembelajaran kita harus memberikan nilai-nilai keagamaan kepada para siswa, tetapi matapelajaran yang kita bawakan bukanlah materi agama. Jadi bagimana strategi kita agar materi kita sampai dan nilai keagamaannya juga dapat?

e) Di dalam suatu kelas kemampuan siswa itu bervariasi ada yang pintar, sedang dan bodoh. Bagaimana strategi yang kita gunakan agar siswa yang bodoh dapat memahami materi yang diberikan dan mampu mengikuti teman-temannya yang berkemampu-an sedang dan pintar?

f) Dalam memilih strategi pembelajaran, kita harus mengetahui psikologi peserta didik. Jadi bagaimana kita bisa mengetahui psikologi peserta didik? g) Bagaimana strategi kita menghadapi orang tua dari peserta didik yang menyalahkan pendidik dalam mendidik anaknya disekolah? Padahal tugas mendidik anak adalah bukan di sekolah saja melainkan pengaruh yang paling besar ialah pendidikan keluarga.

h) Strategi pembelajaran apa yang bisa kita terapkan ketika kita dihadapkan pada seluruh siswa dalam satu ruangan adalah siswa yang super aktif?

Berdasarkan pertanyaanpertanyaan yang diajukan para peserta workshop tersebut maka dapat dikatakan bahwa kegiatan berjalan dengan lancar sesuai yang diharapkan, menambah informasi dan pengetahuan bagi peserta ini didasari karena antusias peserta dalam mengikuti persentase dari awal sampai akhir kegiatan dan rasa percaya diri guru-guru sudah semakin terbangun terkait strategi, dimana pada akhir kegiatan seorang guru melakukan praktek mengajar secara singkat atas pengetahuan yang sudah diperoleh dan berikut adalah gambar salah satu guru yang sedang mempraktekkan strategi pembelajaran.

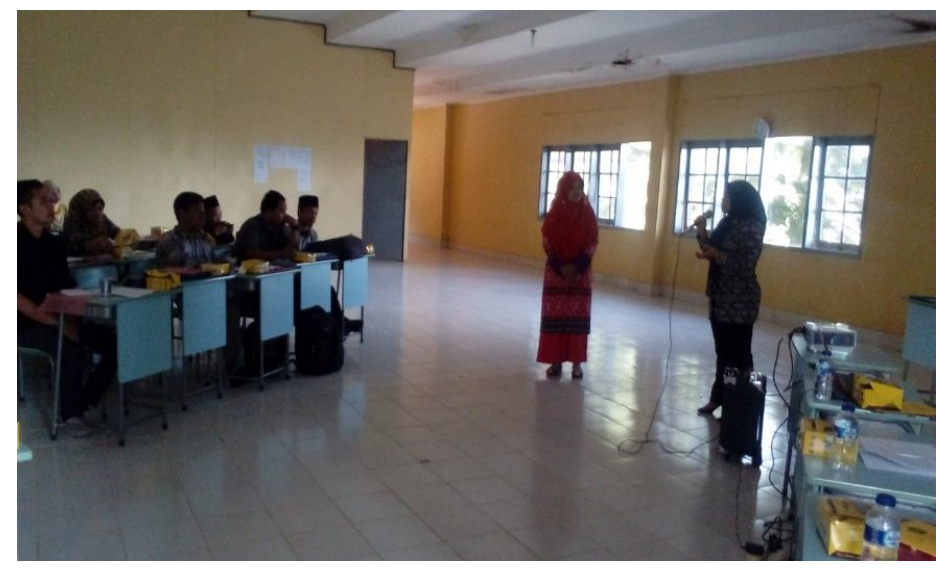

Gambar 2: Praktek Mengajar Salah Satu Peserta Workshop 
Terkait Penggunaan Strategi Pembelajara Dari hasil evalusi yang dilakukan terhadap peserta yang sudah mempraktekkan salah strategi pembelajaran ialah peserta sudah mampu menggambarkan pemahaman dan pengetahuan guru terkait

\section{Hari ke-2}

Kegiatan workshop pada hari ke dua ini merupakan puncak dari kegiatan workshop karena pada hari ke dua ini membahas seputar pengembangan bahan ajar. Pengembangan bahan ajar merupakan kegiatan dalam menghasilkan produk (bahan ajar) baru maupun menyempurnakan produk (bahan ajar) yang sudah ada. Pada kegiatan ini Tim Pengabdian masyarakat mempersentasekan terkait apa itu bahan ajar, manfaat bahan ajar, menjelaskan pengembangan bahan ajar penggunaan strategi dan juga sudah mampu mengembangkan atau memodifikasi dengan lingkungan sekitar sehingga diharapkan nantinya materi yang sudah disampaikan kepada para peserta didik semakin mudah dan menyenangkan.

dan pembimbingan dalam membuat disain pengembangan bahan ajar.

Berdasarkan hasil pengamatan dan hasil pelaksanaan maka kegiatan workshop ini memberikan hal-hal yang baru bagi para peserta workshop dan sekaligus memberikan manfaat yang besar untuk perbaikan pembelajaran kedepannya, diamana sebelumnya para guru belum pernah diberikan seminar/workshop terkait pengembangan bahan ajar. Berikut adalah foto kegiatan pelaksanaan workshop terkait persentase pengembangan bahan ajar.

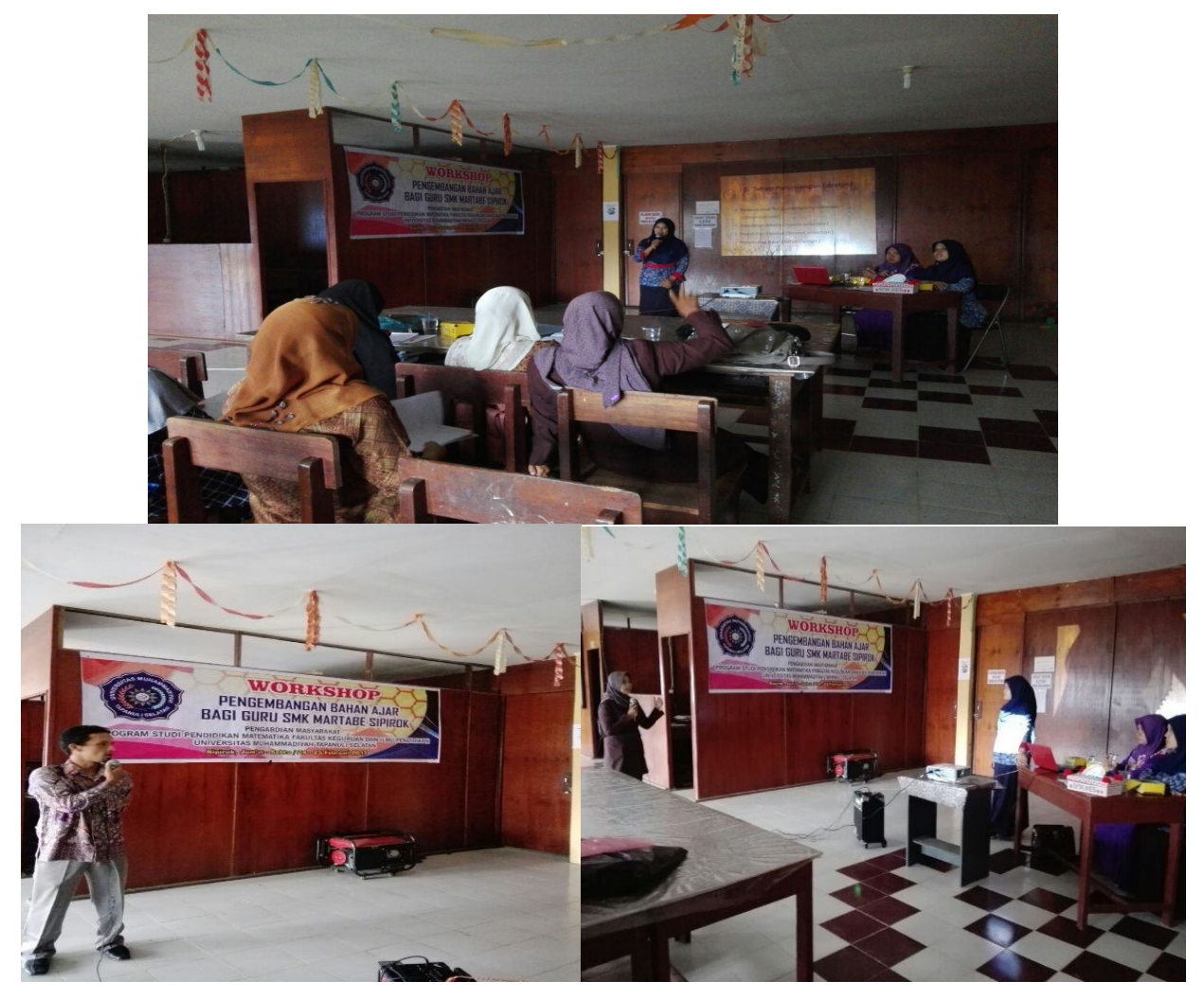

Gambar 3: Antusias peserta dalam mengajukan pertanyaan terkait 
Fitriani, dkk. Workshop Pengembangan Bahan Ajar di SMK Kesehatan ...

Pengembangan Bahan Ajar Kegiatan ini dapat dikatakan berhasil dan terlaksana hal ini juga di dasarkan pada antusias para peserta mengikuti kegiatan dan antusias dalam mengajukan pertanyaan. Berikut adalah pertanyaan-pertanyaan yang diajukan para peserta workshop:

a) Bagaimana cara kita mengembangkan bahan ajar apabila materi yang kita bawakan itu harus memerlukan praktek seperti materi Listening pada materi B.Inggris?

b) Dalam mengembangkan bahan ajar kita harus memperhatikan psikologi peserta didik, pada saat kapan kita memperhatikannya?

c) Pada saat kapan bahan ajar yang kita kembangkan itu dapat digunakan?

d) Seperti apa deains buku ajar yang kita kembangkan jika kita ingin mengembangkan bahan ajar berupa produk baru?

e) Pengembangan bahan ajar itu sebaiknya melibatkan lingkungan sekitar ataupun kehidupan sehari-hari para siswa. Jika kita melibatkan lingkungan sekitar siswa bagaimana siswa kita akan mengetahui lingkungan di luar lingkungannya. Apakah ini tidak akan membuat siswa kita tidak mampu bersaing dengan sekolah lainnya?

f) Jika kita mengembangkan bahan ajar sendiri dan tidak memakai bahan ajar yang ditawarkan oleh pemerintah, apakah ini tidak akan berpengaruh terhadap siswa yang akan mengikuti UN nantinya? g) Dalam pengembangan bahan ajar kita harus melakukan validasi terhadap para ahli. Jadi para ahli yang dimaksud itu apakah harus memiliki tingkatan pendidikan yang lebih tinggi dari pendidikan kita?

h) Pengembangan bahan ajar berupa menyempurnaan produk yang sudah ada, apakah kita boleh membuang materi dan menambah materi yang kita inginkan?

i) Berapa kali kita harus menguji coba bahan ajar yang sudah dikembangkan tersebut dan berapa lama bahan ajar yang kita kembangkan bisa digunakan?

Berdasarkan pengamatan terhadap pertanyaan-pertanyaan yang diajukan oleh para peserta terlihat bahwa para peserta sudah memiliki gambaran terkait pengembangan bahan ajar yang akan dibuat. Peserta workshop juga antusian mengikuti jalannya kegiatan workshop ini dapat dilihat dari banyaknya peserta yang merespon/bertanya terkait materi yang disajikan.

Jenis pertanyaan yang diajukan maka dapat disimpulkan bahwa para peserta sudah banyak memiliki informasi/pengetahuan terkait pengembangan bahan ajar sehingga kegiatan yang dilaksanakan dapat terlaksana sesuai yang diharapkan. Dimana pada akhir pertemuan diberikan kesempatan bagi peserta untuk membuat contoh draf pengembangan bahan ajar dan mempersentasekannya di depan peserta lain dan ini dapat dilihat pada gambar berikut. 


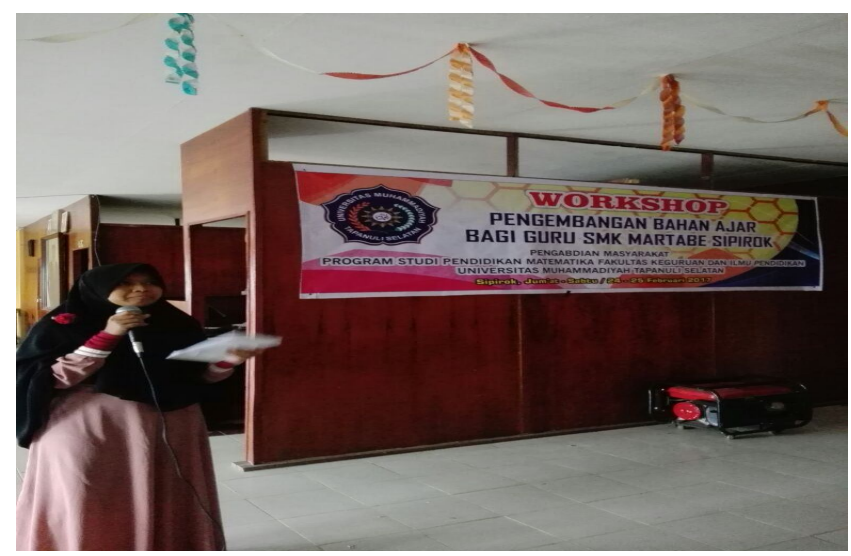

Gambar 4: Persentase Peserta Terkait Draf/Kerangka Pengembangan Bahan Ajar

Dari hasil evalusi yang dilakukan terhadap peserta yang sudah mempraktekkan salah draf/kerangka pengembangan bahan ajar ialah peserta sudah mampu menggambarkan pemahaman dan pengetahuan yang mendalam terkait langkah-langkah pengembangan bahan ajar yang disesuaikan dengan penggunaan strategi dan juga sudah mampu menyusun pokok-pokok pikiran dari pengembangan bahan ajar yang sesuai dengan bidang studi masing-masing.

Hasil hari ke-1 dan hari ke-2 menunjukkan bahwa kegiatan workshop dapat berjalan sesuai yang direncanakan. Ini didasarkan pada antusias peserta dan hasil praktek peserta dalam mengikuti dan mengajukan pertanyaan-pertanyaan terkait materi yang disampaikan. Berdasarkan hal tersebut maka guruguru di SMK Kesehatan Martabe Sipirok sudah banyak memperoleh motivasi, informasi/pengetahuan terkait dalam pengembangan bahan ajar dan juga diperkirakan kedepannya para guru-guru khususnya di SMK Kesehatan Martabe Sipirok sudah mampu mengembangkan bahan ajar sendiri.

\section{SIMPULAN}

Berdasarkan hasil kegiatan workshop yang sudah dilakukan, maka diperoleh kesimpulan bahwa diperoleh feedbac yang positif dari pihak sekolah, guru-guru SMK Kesehatan Martabe Sipirok selama mengikuti kegiatan workshop. Bertambahnya informasi, pengetahuan, dan pemahaman guruguru SMK Kesehatan Martabe Sipirok terkait dalam pengembangan bahan ajar serta sudah mampu mengagambarkan kerangka ataupun draf sederhana dari langkah pengembangan bahan ajar. Guru-guru SMK Kesehatan Martabe Sipirok sudah mampu merancang dan mengembangkan bahan ajar sendiri. Tingginya motivasi yang dimiliki oleh guru-guru SMK Kesehatan Martabe Sipirok dalam melaksanakan kegiatan workshop.

\section{UCAPAN TERIMA KASIH}

Pada kesempatan ini tim pengabdian mengucapkan terima kasih kepada: Universitas Muhammadiyah Tapanuli Selatan yang telah memeberikan bantuan dana, LPPM Universitas Muhammadiyah Tapanuli Selatan dan SMK Kesehatan Martabe Sipirok. 
Fitriani, dkk. Workshop Pengembangan Bahan Ajar di SMK Kesehatan ...

DAFTAR PUSTAKA

Majid, Abdul. 2011. Perencanaan Pembelajaran Mengembangkan Standar Kompetensi Guru. Bandung: PT Remaja Rosdakarya.

Raharjo, Hendri dan I'anah. 2014. Pengembangan Bahan Ajar Berbasis Komputer dalam Pembelajaran Matematika Pada Pokok Bahasan Kubus dan Balok. Jurnal: EduMa 3(2).
Shulhany, M.A., H. Hasanah., R. Julita dan T. Mulyana. 2015. Pengembangan Bahan Ajar Dimensi Tiga dengan Pendekatan Scientific untuk Siswa. Prosiding Seminar Nasional Matematika dan Pendidikan Matematika UMS.

Siregar, Yulia Anita. 2016. Wawancara terkait Kompetensi Guru-Guru di SMK Kesehatan Martabe Sipirok. Jum'at, 16 Desember 2016. Pukul: 10.00-11.00. 